\title{
Pengaruh Kepemimpinan Dan Disiplin Kerja Terhadap Kinerja Guru SMP Muhammadiyah 44 Pamulang
}

\author{
${ }^{1}$ Sutrisno, Ade Ervin \\ Dosen Fakultas Ekonomi Universitas Pamulang \\ ${ }^{1}$ Email :dosen00035@unpam.ac.id
}

\begin{abstract}
ABSTRAK
Penelitian ini dilaksanakan di SMP Muhammadiyah 44 Pamulang, adapun tujuan penelitian ini adalah untuk mengetahui besarnya pengaruh baik secara parsial ataupun simultan variabel kepemimpinan dan disiplin kerja terhadap kinerja guru di SMP Muhammadiyah 44 Pamulang.

Yang menjadi populasi dalam penelitian ini adalah guru-guru di SMP Muhammadiyah 44 Pamulang berjumah 36 orang, sedangkan yang menjadi sampel untuk dijadikan penelitian ini adalah seluruh guru yang ada di SMP Muhammadiya 44 hal ini berdasarkan teknik sample jenuh. Sebelum melakukan analisis data maka peneliti menguji instrument penlitian dengan cara uji validitas dan reliabilitas baru menganalisis data dengan menggunakan Uji asumsi klasik (normalitas, multikolinearitas, autokorelasi dan heteroskedastisitas) baru regresi linier sederhana dan berganda, uji korelasi dan determinasi serta uji hipotesis secara parsial dan simultan.

Dari hasil uji hipotesis secara parsial kempimpinan terhadap kinerja diperoleh nilai $t_{\text {hitung }}>t_{\text {tabel }}$ atau $(5.425>2,032)$. Dengan demikian maka $\mathrm{H}_{0}$ ditolak dan $\mathrm{H}_{1}$ diterima, Disiplin kerja terhadap kinerja diperoleh nilai $t_{\text {hitung }}>t_{\text {tabel }}$ atau $(6,220>$ 2,032). Dengan demikian maka $\mathrm{H}_{0}$ ditolak dan $\mathrm{H}_{2}$ diterima, sehingga secraa parsial kepemimpinan dan disiplin kerja memiliki pengaruh yang positif dan signifikan terhadap kinerja guru. Dan pengujian secara simultan diperoleh nilai $F_{\text {hitung }}>\mathrm{F}_{\text {tabel }}$ atau $(23.411>2,890)$, dengan demikian maka $\mathrm{H}_{0}$ ditolak dan $\mathrm{H}_{3}$ diterima, hal ini menunjukkan bahwa terdapat pengaruh positif dan signifikan secara simultan antara kepemimpinan dan disiplin kerja terhadap kinerja. Sedangkan dari hasil uji koefisien korelasi besar pengaruh kepemimpinan dan disiplin kerja terhadap kinerja maka diperoleh nilai $R$ (koefisien korelasi) sebesar 0,766 artinya variabel Kepemimpinan $\left(\mathrm{X}_{1}\right)$ dan Disiplin kerja $(\mathrm{X} 2)$ mempunyai tingkat pengaruh atau hubungan yang kuat terhadap Kinerja guru (Y) karena berada diantara 0,60-0,799 kuat, dan dari hasil koefisien determinasi maka diperoleh besar pengaruh kepemimpinan dan disiplin kerja terhadap kinerja guru yaitu sebesar 0,587 (58.7\%).
\end{abstract}

Kata kunci: Kepemimpinan, Disiplin Kerja, Kinerja Guru. 


\section{PENDAHULUAN}

\section{A. Latar Belakang Masalah}

Kepemimpinan di era globalisasi akan mengalami tuntutan yang semakin kompleks. Kepemimpinan adalah sebagai aktivitas untuk mempengaruhi orang-orang supaya diarahkan mencapai tujuan organisasi. Pemimpin yang melaksanakan kepemimpinannya secara efektif dapat mengerahkan pegawai atau bawahannya kearah tujuan yang di cita-citakan. Oleh karena itu, kepemimpinan pada SMP Muhammadiyah 44 Pamulang Timur, memiliki fungsi strategis yang menentukan kinerja pada suatu organisasi. Pemimpin yang melaksanakan kepemimpinannya secara efektif dapat menggerakan karyawannya kearah tujuan yang dicita-citakan akan menjadi panutan teladan dengan hal nya. Peran pemimpin dalan perkembangan organisasi memegang posisi strategis untuk memotivasi pegawai agar berkinerja tinggi dan mengarahkan mereka untuk melakukan aktivitasnya menuju pada pencapaian visi-misi organisasi. Oleh karena itu dibutuhkan kepemimpinan yang bisa memotivasi bawahan, memimpin bawahan untuk berkinerja tinggi, dan mengajak bawahan agar memiliki komitmen untuk mencapai visi misi organisasi.

Disiplin yang ada pada seorang pemimpin merupakan kekuatan pendorong yang mewujudkan suatu perilaku guna mencapai tujuan organisasi. Kedisiplinan adalah kunci keberhasilan suatu organisasi dalam mencapai tujuan. Dengan disiplin yang baik berarti sumber daya manusia sadar dan bersedia mengerjakan semua tugasnya dengan efektif dan efisien. Perilaku sumber daya manusia yang tidak disiplin dapat diekspresikan dalam beberapa hal, yakni : keabsenan, meninggalkan tempat kerja, mengulangi prestasi buruk, mencuri, tidur ketika bekerja, berkelahi, mengancam pimpinan, melanggar aturan, melakukan pelanggaran secara tidak wajar, memperlambat pekerjaan, menolak kerja lembur, menolak kersama dengan rekan/tim, menggunakan obatobatan disaat bekerja, merusak fasilitas, merusak peralatan, menggunakan bahasa atau katakata kotor dan penyogokan secara ilegal.

Disiplin yang baik mencerminkan besarnya tanggung jawab seseorang terhadap tugastugas yang diberikan kepadanya. Kedisplinan merupakan fungsi operatif MSDM yang terpenting karena semakin baik disiplin karyawan, semakin tinggi prestatsi kerja yang dapat dicapainya. Tanpa disiplin yang baik, sulit bagi organisasi, sekolah serta perusahaan untuk mencapi hasil yang optimal. Kedisiplinan harus ditegakkan dalam suatu organisasi atau lingkungan sekolah. Tanpa dukungan disiplin guru yang baik, sulit organisasi untuk mewujudkan tujuannya. Jadi kedisiplinan adalah kunci keberhasilan suatu organisasi dalam mencapai tujuan nya. Namun peningkatan kinerja tidak akan berhasil apabila tidak di dukung dengan sumber daya 
manusia yang paling penting dalam organisasi adalah tingkat kepatuhan dan kedisiplinan dalam dunia kerja untuk meningkatkan prestasi dan kinerja kerja.

Sebagai pendidik yang baik harus mampu menjadi contoh teladan para siswanya, salah satunya dalam hal kedisiplinan, selain mengajarkan mata pelajaran guru pun patut menjadi panutan dalam hal kedisiplinan. Namun yang terjadi dilapangan masih banyak ditemui guru yang tidak menunjukan kedisiplinan nya seperti tidak menaati aturan yang telah di tentukan, masih banyak ditemukan guru yang tidak masuk tanpa keterangan, dan lainnya.

Ketidak hadiran guru menjadikan sesuatu yang sangat penting atau disebut mahal karena ketidak hadiran dapat menyebabkan pekerjaan menjadi terbengkalai. Kinerja adalah sesuatu yang ingin dicapai atau prestasi yang akan terlihat pada organisasi atau instansi. Kinerja sebagai kemajuan dan tingkat penyelesaian dalam pekerjaan baik kualitas dan kuantitasnya yang harus meningkat dari waktu ke waktu. Dengan kata lain kinerja adalah meningkatkan standar hasil kerja yang dapat dicapai seseorang atau kelompok dalam rangka mencapai tujuan organisasi bersangkutan secara legal, tidak melanggar hukum dan sesuai dengan moral maupun etika.

Berdasarkan kesimpulan diatas, maka dapat disimpulkan kinerja adalah suatu hasil kerja seseorang, dalam suatu proses atau pelaksanaan tugasnya sesuai dengan tanggung jawabnya dan seberapa banyak pengaruhnya terhadap pencapaian tujuan organisasi. Yang nantinya akan mengarahkan daya dan potensi yang dimiliki agar mau bekerjasama secara produktif untuk mencapai serta mewujudkan tujuan yang sudah ditentukan. Kinerja mengajar guru merupakan penampilan atau perwujudan nyata dari tugas utama guru sebagai pelaksana pengajar. Selama guru menunaikan tugas utama sebagai pendidik, pengajar, pembimbing, pengarah, pelatihan, penilaian dan pengevaluasian peserta didik artinya guru tersebut dapat menunjukan kinerja nya dalam mengajar disekolah. Kinerja kerja yang diharapkan oleh instansi tidak akan dapat tercapai tanpa adanya hubungan antara pemimpin dan bawahan atau antara instansi dan karyawan. Guru atau pengajar merupakan profesi profesional dimana mereka dituntut agar berupaya semaksimal mungkin dalam menjalankan profesinya.

Hasil observasi fenomena mendasar yang peneliti lakukan dilokasi penelitian yaitu kurang tegasnya pimpinan dalam mengambil sebuah keputusan, kurang efektinya pengawasan pemimpin, masih adanya guru yang tidak masuk tanpa keterangan, masih banyak guru yang ijin disaat jam mengajar berlangsung, dan kurangnya sanksi hukuman pada karyawan. Hal ini dapat mempengaruhi kinerja guru, penilaian hasil belajar siswa. Sebagai perencanaan, maka guru harus mampu mendesain pembelajaran yang sesuai dengan kondisi dilapangan, sebagai 
pengelola maka guru harus mampu menciptakan iklim pembelajaran yang kondusif sehingga siswa dapat belajar dengan baik. Dengan demikian kinerja guru dapat diartikan pada sejauh mana seorang guru dapat melakukan tugas dan kewajiban yang sesuai dengan kompetensi yang dimilikinya.

\section{B. Identifikasi Masalah}

Berdasarkan latar belakang penelitian, maka dapat diidentifikasi masalahnya yaitu:

1. Kurangnya ketegasan pimpinan dalam mengambil keputusan dalam suatu masalah pada SMP Muhammadiyah 44 Pamulang.

2. Kurang efektifnya pengawasan pemimpin pada SMP Muhammadiyah 44 Pamulang.

3. Kurangnya disiplin kerja guru pada SMP Muhammadiyah 44 Pamulang.

4. Masih adanya guru yang tidak masuk tanpa keterangan pada
SMP Muhammadiyah 44 pamulang.

5. Kurangnya tindakan atau sanksi hukuman kepada guru yang melanggar aturan pada SMP Muhammadiyah 44 Pamulang.

6. Kinerja guru SMP Muhammadiyah 44 Pamulang belum mencapai hasil Maximal.

\section{Perumusan Masalah}

Berdasarkan hal tersebut di atas maka, perumusan masalah yang akan dibahas adalah :

1. Bagaimana pengaruh kepemimpinan terhadap kinerja guru pada SMP Muhammadiyah 44 Pamulang ?

2. Bagaimana pengaruh disiplin kerja terhadap kinerja guru pada SMP Muhammadiyah 44 Pamulang ?

3. Bagaimana pengaruh kepemimpinan dan disiplin kerja terhadap kinerja guru secara simultan pada SMP Muhammadiyah 44 Pamulang?

\section{Kerangka Berpikir}

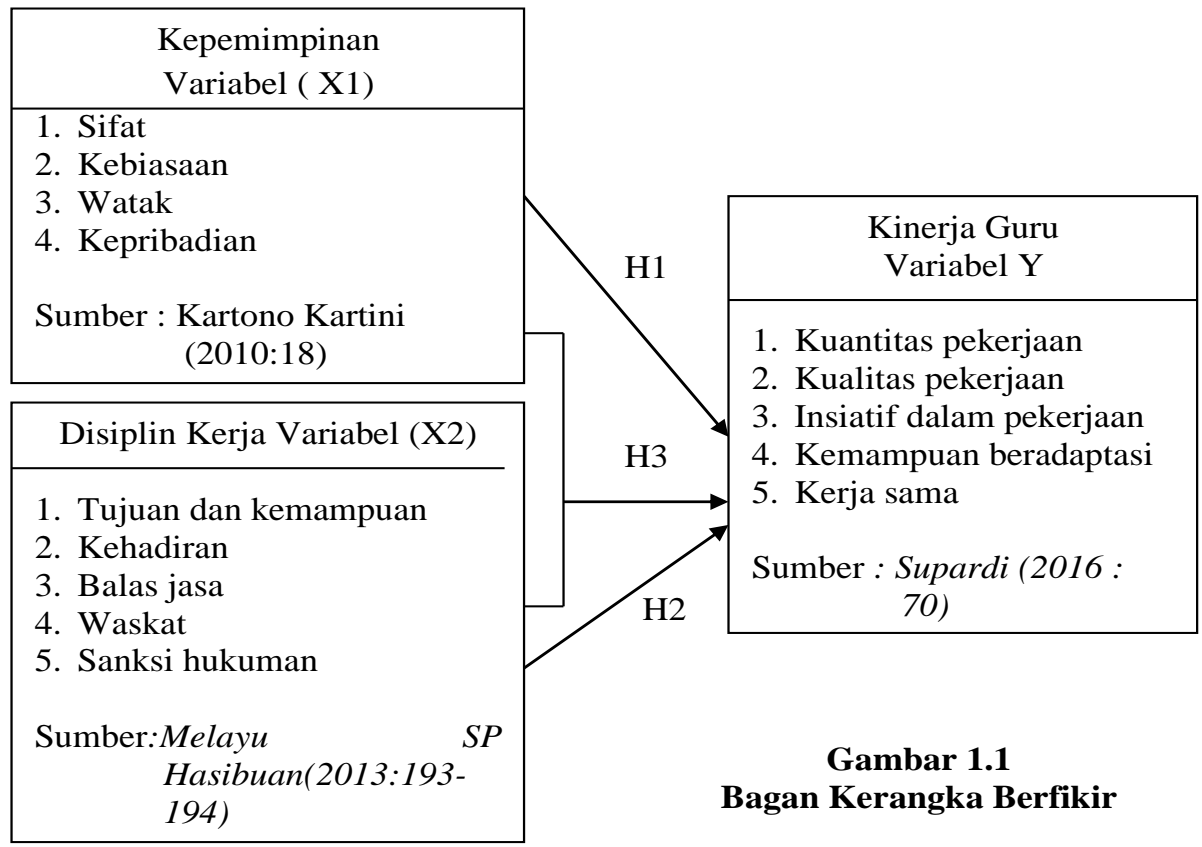




\section{E. Hipotesis}

Hipotesis Berdasarkan pada perumusan masalah dan tujuan penelitian, maka hipotesis dalam penelitian ini adalah:

Ho1 : $\beta_{1}=0$ terdapat pengaruh antara

kepemimpinan

terhadap kinerja guru

Pada SMP

Muhammadiyah 44

Pamulang.

Ha1 : $\beta_{1} \neq 0$ tidak terdapat pengaruh

kepemimpinan

terhadap kinerja guru

Pada SMP

Muhammadiyah 44

Pamulang.

$\mathrm{Ho}^{2}: \beta^{2}=0$ terdapat pengaruh disiplin kerja terhadap kinerja guru Pada SMP

Muhammadiyah 44

Pamulang.

$\mathrm{H} \alpha^{2}: \beta^{2} \neq 0$ tidak terdapat pengaruh disiplin kerja terhadap kinerja guru Pada SMP

Muhammadiyah 44 Pamulang.

$\mathrm{Ho}^{3}: \beta^{3}=0$ terdapat pengaruh kepemimpian dan disiplin kerja terhadap kinerja guru Pada SMP Muhammadiyah 44 Pamulang.

$\mathrm{H}^{2}: \beta^{2} \neq 0$ tidak terdapat pengaruh

kepemimpian dan disiplin kerja terhadap kinerja guru Pada

SMP
Muhammadiyah 44 Pamulang

\section{TINJAUAN PUSTAKA}

\section{A. Kepemimpinan}

Kepemimpinan adalah seorang pribadi yang memiliki kecakapan dan kelebihan, khususnya kecakapan dan kelebihan di satu bidang sehingga dia mampu mempengaruhi orang lain untuk bersama-sama melakukan aktivitas-aktivitas tertentu demi pencapaian satu atau beberapa tujuan, menurut Kartono Kartini (2010:18). Menurut Edy Sutrisno (2016:213) dalam buku Manajemen Sumber Daya Manusia, kepemimpinan adalah suatu proses kegiatan seseorang untuk menggerakkan orang lain dengan memimpin, membimbing, memengaruhi orang lain, untuk melakukan suatu agar dicapai hasil yang diharapkan.

Menurut Fahmi (2013:68) kepemimpinan merupakan suatu ilmu yang mengkaji secara kompherensif tentang bagaimana mengarahkan, mempengaruhi dan mengawasi orang lain untuk mengerjakan tugas sesuai dengan perintah yang direncanakan. Menurut Iswanto (2013:23) seseorang yang karena kedudukan atau jabatan, kewibawaan memegang kendali atas suatu kelompok, unit, organisasi kemudian mengarahkan atau menetapkan dan menjalankan sutau kegiatan, kebijakan aktivitas, tujuan dan kelompok/ unit/ organisasi tersebut dengan kinerja yang baik dan diharapkan dapat mencapai hasil positif. 
Menurut Gibson dalam Sudaryono (2014:5) kepemimpinan adalah upaya menggunakan berbagai jenis pengaruh yang bukan paksaan untuk memotivasi anggota organisasi agar mencapai tujuan tertentu.Sedangkan menurut Edy Sutrisno dalam buku Manajemen Sumber Daya Manusia (2016:216) kepemimpinan adalah gejala universal yang ada pada setiap kelompok manusia sebagai sebuah sistem sosial, mulai dari kelompok kecil yang terdiri dari beberapa orang sampai pada kelompok besar yang di namakan bangsa.

\section{B. Disiplin Kerja}

Menurut Melayu SP Hasibuan (2013:193-194) yang mengartikan kedisplinan adalah kesadaran dan kesediaan seseorang mentaati semua peraturan perusahaan dan normanorma sosial yang berlaku. Kesadaran disini adalah sikap seseorang yang secara sukarela menaati semua peraturan dan sadar akan tugas dan tanggung jawabnya, sedangkan kesediaan adalah suatu sikap, tingkah laku, perbuatan seseorang yang sesuai dengan perusahaan baik tertulis maupun tidak. Menurut Edy Sutrisno dalam buku manajemen sumber daya manusia (2016:86) mengatakan disiplin adalah sikap kesedian dan kerelaan seseorang untuk mematuhi dan menaati norma-norma peraturan yang berlaku di sekitarnya.

Menurut Keith Davis seperti yang dikutip A.A Anwar Prabu Mangkunegara (2013: 129) mengemukakan disiplin adalah "Discipline is management action to enforce organization standart. Artinya disiplin kerja dapat diartikan sebagai pelaksanaan manajemen untuk memperteguh pedoman-pedoman organisasi Menurut Rivai (2011:199) disiplin kerja adalah suata alat untuk berkomunikasi dengan karyawan agar mereka bersedia mengubah suatu perilaku serta sebagai suatu upaya untuk meningkatkan kesadaran dan kesediaan seseorang menaati peraturan perusahaan dan norma-norma sosial yang berlaku.

Menurut Singodimedjo
dalam Sutrisno mengatakan bahwa disiplin adalah sikap kesediaan dan kerelaan untuk mematuhi dan menaati norrma-norma yang berlaku disekitarnya. Disiplin karyawan yang baik akan mempercepat tujuan perusahaan, sedangkan disiplin yang merosot akan menjadi penghalang dan memperlambat tujuan perusahaan. Dengan demikian disiplin sangatlah baik bagi individu yang bersangkutan maupun oleh organisasi.

\section{Kinerja}

Pengertian Kinerja menurut Hasibuan (2013:93) adalah suatu hasil yang dicapai seseorang dalam melaksanakan tugas-tugasnya yang dibebankan kepadanya. Menurut Bambang Gurinto dan Basri (2005) yang dikutif R Yudi Permadi dalam buku Citra Karyawan Disiplin (2013:14 ) kinerja merupakan perbandingan hasil kerja yang dicapai oleh karyawan dengan standar yang terlah ditentukan. Menurut A.A. Anwar Prabu Mangkunegara 
(2013:67) mengemukakan kinerja adalah hasil kerja secara kualitas dan kuantitas yang dicapai oleh seseorang pegawai dalam melaksanakan tugasnya sesuai dengan tanggung jawab yang diberikan kepadanya.

Menurut Wibowo (2014:85) kinerja adalah fungsi atribut individu, organisasi dan lingkungan sehingga dirumuskan model persamaan kinerja. Menurut Rivai dan Basri (2005) yang dikutif R Yudi Permadi dalam buku Citra Karyawan Disiplin (2013:15) pengertian kinerja adalah kesediaan seseorang atau kelompok orang untuk melakukan sesuatu kegiatan yang menyempurnakan sesuai dengan tanggung jawab dengan hasil seperti yang diharapkan. Menurut undang-undang Republik Indonesia No.14 Tahun 2005 tentang Guru dan Dosen. Guru adalah pendidik professional dengan tugas utama mendidik, mengajar, membimbing, mengarahkan, melatih, menilai, dan mengevaluasi peserta didik pada pendidikan usia dini, pendidikan dasar, dan pendidikan menengah. Dalam undang-undang NO.14 tahun 2005 dijelaskan bahwa guru mempunyai kedudukan sebagai tenaga professional pada jenjang pendidikan usia dini, pendidikan dasar dan pendidikan menengah

Kinerja guru merupakan kemampuan seseorang guru dalam melaksanakan tugas pembelajaran disekolah dan bertanggung jawab atas peserta didik dibawah bimbingan nya, dengan meningkatkan prestasi belajar peserta didik. Oleh karena itu kinerja guru dapat di artikan sebagai hasil yang ditampilkan guru dalam melakukan aktivitas pembelajaran. Supardi dalam Kinerja Guru (52:2016). Dari uraian tentang kinerja guru dapat disimpulkan bahwa kinerja guru adalah kemampuan yang ditunjukan oleh guru dalam melaksanakan pekerjaannyas sebagai pendidik. Kinerja dapat dikatakan baik dan memuaskan apabila tujuan yang dicapai sesuai dengan standar yang telah ditetapkan.

\section{METODE PENELITIAN}

Penelitian ini dilaksanakan di PT. Mega Perintis Tbk yang beralamat di Jalan Karet Pedurenan No. 240, Karet Kuningan - Setiabudi, Jakarta Selatan. No. Tlp : 0215733888. Jenis penelitian ini adalah deskriptif kuantitatif, populasi karyawan 36 guru, teknik pengambilan sample menggunakan sample jenuh yaitu seluruh populasi dijadikan sampel

Metode pengumpulan data menggunakan data primer yaitu observasi dan penyebaran kuesioner serta data sekunder yaitu dokumentasi dan studi kepustakaan, uji instrumen penelitian menggunakan uji validitas dan uji reliabilitas, uji asumsi klasik, dalam penelitian ini uji asumsi klasik yang digunakan adalah meliputi: uji normalitas, uji multikolinearitas, uji autokorelasi, dan uji heterokedastisitas.

Metode analisis data menggunakan analisis deskriptif, adapun tahapan analisis yang dilakukan adalah analisis regresi linier sederhana dan linier berganda, 
analisis koefisien korelasi (R), analisis koefisien determinasi $(R$ Square), pengujian hipotesis

\section{HASIL PENELITIAN}

Pengujian Instrumen Penelitian.

\section{Uji Validitas.}

Tabel 4.1

Pengujian Validitas

\begin{tabular}{|c|c|c|c|c|c|}
\hline Pernyataan & $\begin{array}{c}\text { Chronbatch } \\
\text { Alpha } \\
\text { Kepemimpinan }\end{array}$ & $\begin{array}{c}\text { Chronbatch } \\
\text { Alpha } \\
\text { Disiplin }\end{array}$ & $\begin{array}{c}\text { Chronbatch } \\
\text { Alpha } \\
\text { Kinerja }\end{array}$ & $\begin{array}{c}\text { Standar } \\
\text { Chronbatch } \\
\text { Alpha }\end{array}$ & Keputusan \\
\hline 1 & 0.600 & 0.332 & 0.348 & 0.30 & Valid \\
\hline 2 & 0.677 & 0.338 & 0.622 & 0.30 & Valid \\
\hline 3 & 0.575 & 0.592 & 0.325 & 0.30 & Valid \\
\hline 4 & 0.565 & 0.512 & 0.720 & 0.30 & Valid \\
\hline 5 & 0.512 & 0.489 & 0.500 & 0.30 & Valid \\
\hline 6 & 0.421 & 0.463 & 0.444 & 0.30 & Valid \\
\hline 7 & 0.360 & 0.575 & 0.679 & 0.30 & Valid \\
\hline 8 & 0.502 & 0.558 & 0.473 & 0.30 & Valid \\
\hline 9 & 0.578 & 0.478 & 0.367 & 0.30 & Valid \\
\hline 10 & 0.425 & 0.680 & 0.386 & 0.30 & Valid \\
\hline
\end{tabular}

Sumber: Data Primer (Diolah).

Berdasarkan data tabel di atas diperoleh nilai Chronbatch Alpha lebih besar dari 0,30, maka semua item kuesioner dinyatakan valid. Untuk itu kuesioner yang digunakan layak untuk diolah sebagai data penelitian.

\section{Uji Reliabilitas.}

Tabel 4.2

Hasil Uji Reliabilitas Variabel Independen dan Dependen

\begin{tabular}{|c|l|c|c|l|}
\hline No. & \multicolumn{1}{|c|}{ Variabel } & $\begin{array}{c}\text { Coeficient } \\
\text { Alpha }\end{array}$ & $\begin{array}{c}\text { Standar } \\
\text { Chronbach } \\
\text { Alpha }\end{array}$ & Keputusan \\
\hline 1 & Kepemimpinan (X1) & 0.700 & 0.60 & Reliabel \\
\hline 2 & Disiplin kerja (X2) & 0.670 & 0.60 & Reliabel \\
\hline 3 & Kinerja Guru (Y) & 0.649 & 0.60 & Reliabel \\
\hline
\end{tabular}

Sumber: Data Primer diolah.

Berdasarkan hasil pengujian pada tabel di atas, menunjukkan bahwa variabel Kepemimpinan $\left(\mathrm{X}_{1}\right)$, Disiplin kerja $\left(\mathrm{X}_{2}\right)$ dan Kinerja guru
(Y) dinyatakan reliabel, hal itu dibuktikan dengan masingmasing variabel memiliki nilai coeficien Alpha lebih besar dari Chronbath Alpha 0,60. 
C. Pengujian Asumsi Klasik

(Uji Prasyarat Data)

a. Uji Normalitas

Tabel 4.3

Hasil Uji Normalitas Dengan

Kolmogorov-Smirnov Test Tests of Normality

\begin{tabular}{|c|c|c|c|c|c|c|}
\hline \multicolumn{7}{|c|}{ Tests of Normality } \\
\hline \multirow{4}{*}{$\begin{array}{c}\text { Kolmogorov- } \\
\text { Smirnova }\end{array}$} & \multicolumn{2}{|c|}{ Shapiro-Wilk } \\
\cline { 2 - 7 } & $\begin{array}{c}\text { Statist } \\
\text { ic }\end{array}$ & df & Sig. & Statistic & df & Sig. \\
\hline Kinerja Guru (Y) & .084 & 36 & .20 & .977 & 3 & .63 \\
& & & $0^{*}$ & & 6 & 0 \\
\hline
\end{tabular}

${ }^{*}$. This is a lower bound of the true significance.

a. Lilliefors Significance Correction

Sumber: Data primer diolah.

Berdasarkan hasil pengujian pada tabel di atas, diperoleh nilai signifikansi $\alpha$ $=0,200$ dimana nilai tersebut lebih besar dari nilai $\alpha=$ 0,050 atau $(0,200>0,050)$. Dengan demikian maka asumsi distribusi persamaan pada uji ini adalah normal.

b. Uji Multikolinearitas

Tabel 4.4

Hasil Pengujian Multikolinearitas

Dengan Collinearity Statistic

Kinerja guru Sebagai Variabel

Dependen

\begin{tabular}{|l|c|c|}
\hline \multirow{2}{*}{ Variabel } & \multicolumn{2}{|c|}{$\begin{array}{c}\text { Colinerity } \\
\text { Statistics }\end{array}$} \\
\cline { 2 - 3 } & $\begin{array}{c}\text { Toleranc } \\
e\end{array}$ & VIF \\
\hline $\begin{array}{l}\text { Kepemimpina } \\
\mathrm{n}(\mathrm{X} 1)\end{array}$ & 0.499 & $\begin{array}{c}2.00 \\
5\end{array}$ \\
\hline $\begin{array}{l}\text { Disiplin kerja } \\
\text { (X2) }\end{array}$ & 0.499 & $\begin{array}{c}2.00 \\
5\end{array}$ \\
\hline \multicolumn{2}{|c|}{ Sumber : Data primer diolah. } \\
\hline
\end{tabular}

Berdasarkan hasil

pengujian multikolinieritas pada tabel di atas diperoleh nilai tolerance masingmasing variabel bebas yaitu kepemimpinan sebesar 0.499 dan Disiplin kerja sebesar 0.499 , dimana kedua nilai tersebut kurang dari 1, dan nilai Variance Inflation Factor (VIF) variabel kepemimpinan sebesar 2.005 serta Disiplin kerja sebesar 2.005 dimana nilai tersebut kurang dari 10. Dengan demikian model regresi ini tidak ada multikolinearitas.

\section{c. Uji Autokorelasi}

Tabel 4.5

Uji Durbin-Watson

\begin{tabular}{|c|c|c|c|c|c|}
\hline \multicolumn{6}{|c|}{ Model Summary $^{b}$} \\
\hline $\begin{array}{l}\text { Mod } \\
\text { el }\end{array}$ & $R$ & $\begin{array}{c}\text { R } \\
\text { Squa } \\
\text { re }\end{array}$ & $\begin{array}{c}\text { Adjust } \\
\text { ed R } \\
\text { Squar } \\
e\end{array}$ & $\begin{array}{c}\text { Std. } \\
\text { Error } \\
\text { of the } \\
\text { Estima } \\
\text { te }\end{array}$ & $\begin{array}{c}\text { Durbi } \\
\text { n- } \\
\text { Wats } \\
\text { on }\end{array}$ \\
\hline 1 & $\begin{array}{l}.76 \\
6^{\mathrm{a}} \\
\end{array}$ & .587 & .562 & 2.360 & 1.952 \\
\hline
\end{tabular}

a. Predictors: (Constant), Disiplin kerja

(X2), Kepemimpinan (X1)

b. Dependent Variable: Kinerja Guru (Y) Sumber: Data primer diolah.

Berdasarkan hasil pengujian pada tabel di atas, model regresi ini tidak ada autokorelasi, hal ini dibuktikan dengan nilai Durbin-Watson sebesar 1.952 yang berada diantara interval $1.550-2.460$, “ Tidak Ada Autokorelasi" Sesuai dengan teori Sugiyono (2016:184). 


\section{d. Uji Heteroskedastisitas}

Tabel 4.6

Hasil Pengujian Heteroskesdastisitas

Dengan Uji Glejser

\begin{tabular}{|c|c|c|c|c|c|}
\hline \multicolumn{6}{|c|}{ Coefficients $^{\mathrm{a}}$} \\
\hline \multirow[b]{2}{*}{ Model } & \multicolumn{2}{|c|}{$\begin{array}{l}\text { Unstandardi } \\
\text { zed } \\
\text { Coefficients }\end{array}$} & \multirow{2}{*}{$\begin{array}{c}\begin{array}{c}\text { Standardi } \\
\text { zed } \\
\text { Coefficient } \\
s\end{array} \\
\text { Beta }\end{array}$} & \multirow[b]{2}{*}{$\mathrm{t}$} & \multirow[b]{2}{*}{ Sig } \\
\hline & B & $\begin{array}{l}\text { Std. } \\
\text { Error }\end{array}$ & & & \\
\hline \begin{tabular}{l|l}
1 & (Constant)
\end{tabular} & $\begin{array}{c}4.95 \\
5\end{array}$ & 2.728 & & $\begin{array}{c}1.81 \\
7\end{array}$ & $\begin{array}{c}.07 \\
8\end{array}$ \\
\hline $\begin{array}{l}\text { Kepemimpi } \\
\text { nan (X1) }\end{array}$ & .017 & .090 & .045 & .188 & $\begin{array}{c}.85 \\
2\end{array}$ \\
\hline $\begin{array}{l}\text { Disiplin } \\
\text { kerja (X2) }\end{array}$ & -.099 & .091 & -.262 & $\begin{array}{c}- \\
1.09 \\
1\end{array}$ & $\begin{array}{c}- \\
.28 \\
3\end{array}$ \\
\hline
\end{tabular}

Berdasarkan hasil pengujian pada tabel di atas, glejser test model pada variabel Kepemimpinan $\left(\mathrm{X}_{1}\right)$ diperoleh nilai probability signifikansi (Sig.) sebesar 0,852 dan Disiplin kerja $\left(\mathrm{X}_{2}\right)$ diperoleh nilai probability signifikansi (Sig.) sebesar 0, 283 dimana keduanya nilai signifikansi (Sig.) > 0,05. Dengan demikian regression model pada data ini tidak ada gangguan

heteroskesdastisitas,

sehingga model regresi ini layak dipakai sebagai data penelitian.

D. Analisis

Deskriptif

dan Verifikatif

1. Analisis

Deskriptif

Karakteristik Responden

a. Karakteristik Responden Berdasarkan Jenis Kelamin

Tabel 4.7

Karakteristik Responden Berdasarkan Jenis Kelamin

\begin{tabular}{|c|c|c|c|c|c|}
\hline \multicolumn{6}{|c|}{\begin{tabular}{|l} 
Jenis Kelamin \\
\end{tabular}} \\
\hline & & \multirow{2}{*}{$\begin{array}{c}\begin{array}{c}\text { Frequ } \\
\text { ency }\end{array} \\
22\end{array}$} & \multirow{2}{*}{$\begin{array}{c}\text { Perc } \\
\text { ent }\end{array}$} & $\begin{array}{c}\text { Vali } \\
d \\
\text { Perc } \\
\text { ent }\end{array}$ & $\begin{array}{c}\text { Cumul } \\
\text { ative } \\
\text { Percen } \\
t\end{array}$ \\
\hline \multirow[t]{3}{*}{$\begin{array}{l}\text { Va } \\
\text { lid }\end{array}$} & $\begin{array}{l}\text { Laki- } \\
\text { Laki }\end{array}$ & & & 61.1 & 61.1 \\
\hline & Perem & 14 & 38.9 & 38.9 & 100.0 \\
\hline & Total & 36 & $\begin{array}{c}100 . \\
0\end{array}$ & $\begin{array}{c}100 . \\
0\end{array}$ & \\
\hline
\end{tabular}

Sumber : Data primer diolah.

Berdasarkan data di atas, responden yang berjenis kelamin laki-laki sebanyak 22 orang atau $61,1 \%$, sedangkan yang berjenis kelamin perempuan sebanyak 14 orang atau $38,9 \%$. Sehingga mayoritas Guru di SMP Muhammadiyah 44 Pamulang adalah laki-laki maka tidak ada perbedaan yang signifikan kompetensi guru antara guru laki-laki dan perempuan dalam pembelajaran, Ruth Suci (2011).

b. Karakteristik Responden Berdasarkan Usia

Tabel 4.8

Karakteristik Responden

Berdasarkan Usia

\begin{tabular}{|c|c|c|c|c|c|}
\hline \multicolumn{6}{|c|}{ Usia } \\
\hline & & Frequency & Percent & $\begin{array}{c}\text { Valid } \\
\text { Percent }\end{array}$ & $\begin{array}{c}\text { Cumulative } \\
\text { Percent }\end{array}$ \\
\hline \multirow[t]{5}{*}{ Valid } & $\begin{array}{l}17-25 \\
\text { Tahun }\end{array}$ & 3 & 8.3 & 8.3 & 8.3 \\
\hline & $\begin{array}{l}\text { 26-35 } \\
\text { Tahun }\end{array}$ & 6 & 16.7 & 16.7 & 25.0 \\
\hline & $\begin{array}{l}\text { 36-45 } \\
\text { Tahun }\end{array}$ & 18 & 50.0 & 50.0 & 75.0 \\
\hline & $\begin{array}{l}>45 \\
\text { Tahun }\end{array}$ & 9 & 25.0 & 25.0 & 100.0 \\
\hline & Total & 36 & 100.0 & 100.0 & \\
\hline
\end{tabular}

Sumber : Data primer diolah.

Data di atas, responden yang berusia antara 17-25 tahun sebanyak sebanyak 3 orang atau 8,3\%, yang 
berusia antara 26-35 tahun sebanyak 6 orang atau $16,7 \%$, yang berusia antara 36-45 tahun sebanyak 18 orang atau $50,0 \%$ dan yang berusia $>45$ tahun sebanyak 9 orang atau $25,0 \%$. Sehingga mayoritas guru yang berusia 36-45 th sebanyak 18 orang.

c. Karakteristik Responden Berdasarkan Pendidikan

Tabel 4.9

Karakteristik Responden

Berdasarkan Pendidikan

\begin{tabular}{|c|c|c|c|c|c|}
\hline \multicolumn{6}{|c|}{ Pendidikan } \\
\hline & & $\begin{array}{c}\text { Freque } \\
\text { ncy }\end{array}$ & $\begin{array}{c}\text { Perc } \\
\text { ent }\end{array}$ & $\begin{array}{l}\text { Valid } \\
\text { Perc } \\
\text { ent }\end{array}$ & $\begin{array}{l}\text { Cumula } \\
\text { tive } \\
\text { Percent }\end{array}$ \\
\hline \multirow{5}{*}{$\begin{array}{l}\text { Val } \\
\text { id }\end{array}$} & SLTA & 4 & 11.1 & 11.1 & 11.1 \\
\hline & $\begin{array}{l}\text { Diplo } \\
\text { ma }\end{array}$ & 5 & 13.9 & 13.9 & 25.0 \\
\hline & $\begin{array}{l}\text { Sarja } \\
\text { na } \\
\text { (S1) }\end{array}$ & 16 & 44.4 & 44.4 & 69.4 \\
\hline & $\begin{array}{l}\text { Sarja } \\
\text { na } \\
\text { (S2) }\end{array}$ & 11 & 30.6 & 30.6 & 100.0 \\
\hline & Total & 36 & $\begin{array}{c}100 . \\
0\end{array}$ & $\begin{array}{c}100 . \\
0\end{array}$ & \\
\hline
\end{tabular}

Sumber : Data primer diolah.

Berdaarkan data di atas, responden yang berpendidikan SLTA sebanyak 4 orang atau $11,1 \%$, berpendidikan Diploma sebanyak 5 orang atau $13,9 \%$ yang berpendidikan $\mathrm{S} 1$ sebanyak 16 orang atau $44,4 \%$, dan yang berpendidikan S2 sebanyak 11 orang atau $30,6 \%$.

\section{d. Penilaian Responden}

Tanggapan

responden atas pernyataan pada variabel kepemimpinan diperoleh rata-rata skor 4.40 termasuk pada rentang skala 3,40 - 4,19 dengan kriteria baik, hal ini juga dapat dilihat dari skor tertinggi pada Indikator "Watak" yaitu sebesar 4,05 maka dimana kepala sekolah memberikan kebebasan untuk menyampaikan pendapat dan menjelasakan tentang keputusan yang ditetapkan kepada guru-guru dengan baik.

Tanggapan responden pada variabel Disiplin kerja diperoleh rata-rata skor 4.06 termasuk pada rentang skala 3,40 - 4,19 dengan kriteria baik, hal ini dibuktikan dari rata skor tertinggi pada idnikator " Sanksi dan Hukuman" yaitu sebesar 4,05 dimana guru yang melanggar aturan diberikan sanksi dengan cepat dan sanksi yang diberikan dijalankan dengan baik, hal ini menandakan bahwa sanksi dan hukuman yang diberikan sudah berjalan dengan baik.

Tanggapan responden variabel kinerja guru dikatakan sudah baik hal ini dilihat dari skor rata-rata yaitu 4,06 dimana berada diantara interval 3,40-4,19 dengan kriteria baik. Dan hal ini dibuktikan dari skor tertinggi pada indikator "Tanggung Jawab" yaitu sebesar 4,05 dimana guru dapat menyelesaiakan pekerjaan sesuai dengan tanggung jawab dan bersedia lembur hal ini dibuktikan juga berdasarkan fenomena yang ada dilapangan bahwa banyak guru yang terkadang belum 
pulang setelah jam ngajar karena harus menyelesaikan pekerjaan.

2. Analisis Verifikatif

a. Analisis Regresi Linier Berganda.

Tabel 4.10

Hasil Pengolahan Regresi

Berganda Variabel Kepemimpinan

( $\left.\mathbf{X}_{1}\right)$ dan Disiplin kerja $\left(\mathbf{X}_{3}\right)$

Terhadap Kinerja guru (Y)

\begin{tabular}{|c|c|c|c|c|c|}
\hline \multirow[b]{3}{*}{ Model } & \multicolumn{5}{|c|}{ Coefficients $^{a}$} \\
\hline & $\begin{array}{r}\text { Unst } \\
\text { diz } \\
\text { Coef } \\
t\end{array}$ & $\begin{array}{l}\text { andar } \\
\text { ed } \\
\text { icien }\end{array}$ & $\begin{array}{c}\text { Standar } \\
\text { dized } \\
\text { Coeffici } \\
\text { ents }\end{array}$ & & \\
\hline & B & $\begin{array}{c}\text { Std. } \\
\text { Erro } \\
r\end{array}$ & Beta & $\mathrm{t}$ & $\begin{array}{l}\mathrm{Si} \\
\mathrm{g} .\end{array}$ \\
\hline 1 (Constant & $\begin{array}{c}9.82 \\
2\end{array}$ & $\begin{array}{c}4.40 \\
6\end{array}$ & & $\begin{array}{l}2.2 \\
29\end{array}$ & $\begin{array}{l}.0 \\
33\end{array}$ \\
\hline $\begin{array}{l}\text { Kepemim } \\
\text { pinan } \\
\text { (X1) }\end{array}$ & .302 & .145 & .330 & $\begin{array}{l}2.0 \\
83\end{array}$ & $\begin{array}{l}.0 \\
45\end{array}$ \\
\hline $\begin{array}{l}\text { Disiplin } \\
\text { kerja (X2) }\end{array}$ & .459 & .147 & .496 & $\begin{array}{l}3.1 \\
28\end{array}$ & $\begin{array}{l}.0 \\
04\end{array}$ \\
\hline
\end{tabular}

a. Dependent Variable: Kinerja Guru (Y)

Sumber: Data Primer diolah

Berdasarkan hasil

analisis perhitungan regresi pada tabel di atas, maka dapat diperoleh persamaan regresi $\mathrm{Y}=9.822+0,302 \mathrm{X}_{1}$ $+0,459 \mathrm{X}_{2}$.

b. Analisis Koefisien Korelasi (r).

Tabel 4.11

Hasil Analisis Koefisien Korelasi

Secara Simultan Antara Variabel

Kepemimpinan $\left(X_{1}\right)$ dan Disiplin

$\operatorname{Kerja}\left(\mathbf{X}_{2}\right)$ Terhadap

Kinerja Guru (Y)

\begin{tabular}{|l|c|r|r|r|}
\hline \multicolumn{5}{|c|}{ Model Summary } \\
\hline & & & $\begin{array}{c}\text { Std. } \\
\text { Adjusted } \\
\mathrm{R}\end{array}$ & $\begin{array}{c}\text { Error of } \\
\text { the } \\
\text { Model }\end{array}$ \\
\hline 1 & $\mathrm{R}$ & $\begin{array}{c}\mathrm{R} \\
\text { Square }\end{array}$ & Square & Estimate \\
\hline
\end{tabular}

a. Predictors: (Constant), Disiplin kerja (X2), semimpinan (X1)

Sumber: Data Primer diolah.
Berdasarkan pada hasil pengujian pada tabel di atas, diperoleh nilai $R$ (koefisien korelasi) sebesar 0,766 artinya variabel Kepemimpinan $\left(\mathrm{X}_{1}\right)$ dan Disiplin kerja (X2) mempunyai tingkat pengaruh atau hubungan yang kuat terhadap Kinerja guru (Y) karena berada diantara 0,60-0,799 "Kuat" Sugiyono (2015:321).

c. Analisis Koefisien Determinasi ( $R$ Square). Tabel 4.12

Hasil Analisis Koefisien Determinasi Secara Simultan Antara Variabel Kepemimpinan $\left(\mathrm{X}_{1}\right)$ dan Disiplin kerja (X2)Terhadap Kinerja guru (Y)

\begin{tabular}{|c|c|c|c|c|}
\hline \multicolumn{5}{|c|}{ Model Summary } \\
\hline sdel & $\mathrm{R}$ & $\begin{array}{c}\mathrm{R} \\
\text { Square }\end{array}$ & $\begin{array}{c}\text { Adjusted } \\
\text { R } \\
\text { Square }\end{array}$ & $\begin{array}{l}\text { Std. } \\
\text { Error of } \\
\text { the } \\
\text { Estimate }\end{array}$ \\
\hline
\end{tabular}

a. Predictors: (Constant), Disiplin kerja (X2), Kepemimpinan (X1)

Sumber: Data Primer diolah.

Berdasarkan pada hasil pengujian pada tabel di atas, diperoleh nilai $R$-square sebesar 0,587 maka dapat disimpulkan bahwa variabel Kepemimpinan $\left(\mathrm{X}_{1}\right)$ dan Disiplin kerja (X2) berpengaruh terhadap variabel Kinerja guru (Y) sebesar $58.7 \%$ sedangkan sisanya sebesar $41.3 \%$ dipengaruhi oleh faktor lain yang tidak dilakukan penelitian.

d. Pengujian Hipotesis.

1) Pengujian Hipotesis Secara Parsial (Uji t). 
(a)Pengaruh

Kepemimpinan

$\left(\mathbf{X}_{1}\right)$

Terhadap Kinerja guru (Y).

Tabel 4.13

Hasil Uji t Variabel

Kepemimpinan $\left(\mathrm{X}_{1}\right)$ - y

\begin{tabular}{|c|c|c|c|c|c|}
\hline \multicolumn{6}{|c|}{ Coefficients $^{a}$} \\
\hline \multirow[b]{2}{*}{ Model } & $\begin{array}{r}\text { Unst } \\
\text { diz } \\
\text { Coef } \\
t\end{array}$ & $\begin{array}{l}\text { andar } \\
\text { ed } \\
\text { icien } \\
\text { icien }\end{array}$ & $\begin{array}{c}\text { Standar } \\
\text { dized } \\
\text { Coeffici } \\
\text { ents } \\
\end{array}$ & & \\
\hline & B & $\begin{array}{c}\text { Std. } \\
\text { Erro } \\
r\end{array}$ & Beta & $t$ & $\begin{array}{l}\mathrm{Si} \\
\mathrm{g} .\end{array}$ \\
\hline 1 (Constant & $\begin{array}{r}15 . \\
088\end{array}$ & $\begin{array}{r}4.56 \\
7 \\
\end{array}$ & & $\begin{array}{r}3.3 \\
04 \\
\end{array}$ & $\begin{array}{l}.0 \\
02 \\
\end{array}$ \\
\hline $\begin{array}{l}\text { Kepemim } \\
\text { pinan } \\
(\mathrm{X} 1)\end{array}$ & $\begin{array}{r}.62 \\
3\end{array}$ & .115 & .681 & $\begin{array}{r}5.4 \\
25\end{array}$ & $\begin{array}{l}.0 \\
00\end{array}$ \\
\hline
\end{tabular}

a. Dependent Variable: Kinerja Guru $(\mathrm{Y})$

Sumber: Data Primer diolah.

Berdasarkan pada hasil pengujian pada tabel di atas diperoleh nilai $t_{\text {hitung }}>t_{\text {tabel }}$ atau $(5.425>2,032)$ Hal tersebut juga diperkuat dengan nilai $\rho$ value < Sig.0,05 atau $(0,000<0,05)$. Dengan demikian maka $\mathrm{H}_{0}$ ditolak dan $\mathrm{H}_{1}$ diterima, hal ini menunjukkan bahwa terdapat pengaruh positif dan signifikan secara parsial antara Kepemimpinan terhadap kinerja guru pada SMP Muhammadiyah 44 Pamulang.

(b) Pengaruh Dsiplin Kerja (X2) Terhadap Kinerja guru (Y)

Tabel 4.14

Hasil Uji t Variabel Disiplin kerja

$\left(\mathbf{X}_{2}\right)-\mathbf{y}$

\begin{tabular}{|l|c|c|c|c|}
\hline \multicolumn{5}{|c|}{ Coefficients $^{\mathbf{a}}$} \\
\hline & $\begin{array}{c}\text { Unstandar } \\
\text { dized }\end{array}$ & $\begin{array}{c}\text { Standard } \\
\text { ized }\end{array}$ & & \\
& Coefficient & Coefficie & & Si \\
Model & $\mathrm{s}$ & nts & t & g. \\
\hline
\end{tabular}

\begin{tabular}{|c|c|c|c|c|c|}
\hline & B & $\begin{array}{c}\text { Std. } \\
\text { Erro } \\
r\end{array}$ & Beta & & \\
\hline $\begin{array}{ll}1 & \text { (Const } \\
\text { ant) }\end{array}$ & $\begin{array}{r}13.2 \\
99 \\
\end{array}$ & $\begin{array}{r}4.27 \\
3 \\
\end{array}$ & & $\begin{array}{r}3.1 \\
13 \\
\end{array}$ & $\begin{array}{r}.0 \\
04 \\
\end{array}$ \\
\hline $\begin{array}{l}\text { Disiplin } \\
\text { kerja } \\
(\mathrm{X} 2)\end{array}$ & .675 & .109 & .730 & $\begin{array}{r}6.2 \\
20\end{array}$ & $\begin{array}{l}.0 \\
00\end{array}$ \\
\hline
\end{tabular}

a. Dependent Variable: Kinerja Guru (Y)

Sumber: Data Primer diolah.

Berdasarkan pada hasil pengujian pada tabel di atas diperoleh nilai $t_{\text {hitung }}>t_{\text {tabel }}$ atau $(6,220>2,032)$. Hal tersebut juga diperkuat dengan nilai $\rho$ value < Sig.0,05 atau $(0,000<0,05)$. Dengan demikian maka $\mathrm{H}_{0}$ ditolak dan $\mathrm{H}_{2}$ diterima, hal ini menunjukkan bahwa terdapat pengaruh yang positif dan signifikan secara parsial antara Disiplin kerja terhadap Kinerja guru pada SMP Muhammadiyah 44 Pamulang.

2) Pengujian Hipotesis Secara Simultan (Uji F). Tabel 4.15

Hasil Hipotesis (Uji F) Simultan

\begin{tabular}{|c|c|c|c|c|c|c|}
\hline \multicolumn{7}{|c|}{ ANOVA $^{a}$} \\
\hline & Model & $\begin{array}{l}\text { Sum } \\
\text { of } \\
\text { Squar } \\
\text { es }\end{array}$ & $\begin{array}{l}d \\
f\end{array}$ & $\begin{array}{l}\text { Mean } \\
\text { Squar } \\
\text { e }\end{array}$ & $\mathrm{F}$ & Sig. \\
\hline 1 & $\begin{array}{c}\text { Regressi } \\
\text { on }\end{array}$ & $\begin{array}{c}260.8 \\
81\end{array}$ & 2 & $\begin{array}{c}130.4 \\
41\end{array}$ & $\begin{array}{c}23.4 \\
11\end{array}$ & $\begin{array}{l}.00 \\
0^{\mathrm{b}}\end{array}$ \\
\hline & Residual & $\begin{array}{c}183.8 \\
69\end{array}$ & $\begin{array}{l}3 \\
3\end{array}$ & 5.572 & & \\
\hline & Total & $\begin{array}{c}444.7 \\
50 \\
\end{array}$ & $\begin{array}{l}3 \\
5 \\
\end{array}$ & & & \\
\hline
\end{tabular}

a. Dependent Variable: Kinerja Guru (Y)

b. Predictors: (Constant), Disiplin kerja

(X2), Kepemimpinan (X1)

Sumber: Data Primer diolah.

Berdasarkan pada hasil pengujian pada tabel di atas diperoleh nilai $F_{\text {hitung }}>\mathrm{F}_{\text {tabel }}$ atau $(23.411>2,890)$, hal ini juga diperkuat dengan $\rho$ value < Sig.0,05 atau $(0,000$ $<0,05)$. Dengan demikian 
maka $\mathrm{H}_{0}$ ditolak dan $\mathrm{H}_{3}$ diterima, hal ini menunjukkan bahwa terdapat pengaruh positif dan signifikan secara simultan antara Kepemimpinan dan Disiplin kerja terhadap Kinerja guru pada SMP Muhammadiyah 44 Pamulang.

\section{KESIMPULAN DAN SARAN}

\section{A. Kesimpulan}

1. Berdasarkan rumusan masalah maka diketahui besarnya pengaruh kepemimpinan terhadap kinerja guru yaitu sebesar 5,425 hal ini diperoleh nilai $\mathrm{t}_{\text {hitung }}>\mathrm{t}$ tabel atau (5.425> 2,032) Hal tersebut juga diperkuat dengan nilai $\rho$ value $<$ Sig.0,05 atau $(0,000<0,05)$.

2. Berdasarkan rumusan masalah maka diketahui besarnya pengaruh disiplin kerja terhadap kinerja guru yaitu sebesar 6,220 hal ini diperoleh nilai $t_{\text {hitung }}>\mathrm{t}_{\text {tabel }}$ atau $(6,220>$ 2,032). Hal tersebut juga diperkuat dengan nilai $\rho$ value $<$ Sig.0,05 atau $(0,000<0,05)$.

3. Berdasarkan rumusan masalah maka diketahui besarnya pengaruh kepemimpinan dan disiplin kerja terhadap kinerja guru yaitu sebesar 23,411, hal ini diperoleh dari nilai $\mathrm{F}$ hitung $>$ $F_{\text {tabel }}$ atau $(23.411>2,890)$, hal ini juga diperkuat dengan $\rho$ value < Sig.0,05 atau $(0,000<$ $0,05)$.

\section{B. Saran}

1. Dari hasil penelitian maka kepemimpinan kepala sekolah yang ada di sekolah masih kurang baik dimana terkadang kepala sekolah tidak mendengarkan saran dari guruguru dan jarang membimbing guru-guru, maka dari itu sebaiknya kepala sekolah harus lebih dekat lagi dengan guru dan menjalin silahturahmi dengan berbagai kegiatan sehingga dapat mendengarkan aspirasi guru-guru yang ingin disampaikanya.

2. Dari hasil penelitian maka disiplin kerja guru masih kurang hal ini dilihat dari kepala sekolah kurang aktif memberikan pengawasan kepada guru dan terkadang jarang merspon dengan cepat terhadap masalah yang dihadapi oleh guru-guru, maka dari itu sebaik nya kepala sekolan harus lebih dekat dan meluangkan waktu untuk guru-guru sehingga dapat memberikan pengasawan secara langsung kepada guru-guru.

3. Dari hasi penelitian maka kinerja guru yang ada disekolah masih kurang hal ini masih terdapat guru yang tidak menguasai pelajaran yang diajarkan sehingga tidak semua pertanyaan siswa dapat dtanggapi dengan baik dan benar, maka dari itu sebaiknya guru yang mengajar mata pelajaran disesuaikan dengan pendidikan akhir dari seoerang guru sehingga guru tersebut dapat benar-benar mengusai mata pelajaran yang diampu. 


\section{DAFTAR PUSTAKA}

Bahrum Syazhashah Putra. 2015. "Pengaruh Kepemimpinan Dan Motivasi Kerja Terhadap

Kinerja Pegawai”. Jurnal Akuntansi, Ekonomi dan Manajemen Bisnis vol. 3, No. 2.

Baihaqi Muhammad Imam. 2013. "Pengaruh Kepemimpinan Dan Disiplin Kerja Terhadap

Kinerja Pegawai”. Jurnal : Dinas Kehutanan Kabupaten Timur. Vol 02, No.04.

Hasibua Malayu S.P. 2013. "Manajemen Sumber Daya Manusia". Jakarta: Penerbit PT Bumi Aksara.

Isvandiari Any. 2018.

"Kepemimpinan Dan Disiplin

Kerja Terhadap Kinerja". Jurnal JIBEKA Volume 12, No 1.

Kartini Kartono. 2010. "Pimpinan Dan Kepemimpinan". Jakarta: Penerbit Raja Grafindo Persada.

Mangkunegara Anwar Prabu. 2013. "Manajemen Sumber Daya Manusia Perusahaan".

Bandung: Penerbit PT Remaja Rosdakarya.

Prambana Sumiarti. 2018. "Pengaruh Disiplin Kerja Dan Kepuasan Kerja Terhadap Kinerja Pegawai". Jakarta. Universitas Islam Negeri Syarif Hidayatullah.

Soleha Lilis Karnita. 2012. "Pengaruh Kepemimpinan, Disiplin Kerja, Dan Komunikasi Terhadap Kinerja Pegawai”. Jurnal Ekonomi, Bisnis dan Entrepreneurship Vol. 6, No. 1. Sugiyono Dr. 2015. "Metode Penelitian Kuantitatif Dan Kualitatif Dan R\&D”.
Bandung. Penerbit: CV Alfa Beta.

Sunarsi, D. (2018). Pengaruh Gaya Kepemimpinan, Motivasi Dan Disiplin Kerja Terhadap Kinerja Pendidik Yayasan Marvin. Inovasi, 5(1), 1-18.

Sunarsi, D. (2017). Pengaruh Disiplin, Motivasi, Dan Kompetensi Terhadap Prestasi Belajar (Studi Kasus Pada Mahasiswa Universitas Pamulang, Tangerang Selatan Tahun Akademik 2016-2017). Jurnal Mandiri, 1(2), 207-226.

Supardi. 2016. "Kinerja Guru". Edisi Ke 3. Jakarta: Penerbit PT Raja Grafindo Persada.

Virgiawan Egy. 2017. "Pengaruh Disiplin Kerja Terhadap Kinerja Pegawai Pada

Pusat Kesehatan Masyarakat Pamulang Tangerang Selatan". Tangerang Selatan. Universitas Pamulang.

Wati Bunga. 2016. "Pengaruh Kepemimpinan, Motivasi Kerja Dan Disiplin Kerja

Terhadap Kinerja”. Jurnal Competitiveness ISSN : 19783035 I Vol. 10, No 2.

Yudi Permadi. 2013. "Citra Karyawan Disiplin". Bandung: Penerbit CV Sanggabuana. 